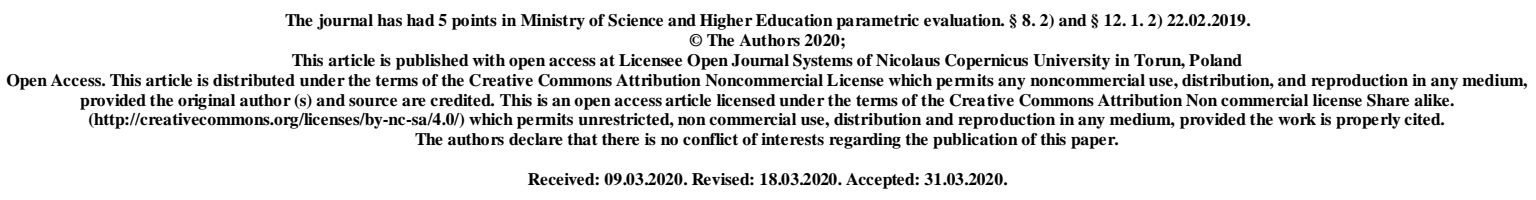

\title{
STATE-PUBLIC ADMINISTRATION OF EDUCATION AS THE MAIN DIRECTION OF DEMOCRATIZATION
}

\author{
Inna Shorobura
}

\author{
Khmelnytskyi Humanitarian-Pedagogical Academy \\ doctor of pedagogical sciences, professor, rector
}

\begin{abstract}
Public administration of the education system is a productive activity of the society, which contains an active manifestation of civic position, social initiative and social responsibility in the management of the education system. The purpose of the article is to emphasize the issues of state-public administration of education as the main direction of democratization in the field of education. There are three levels of state administration in the educational sphere: the national level; regional level; district level.
\end{abstract}

Key words: education; administration; state-public administration of education. 


\title{
ДЕРЖАВНО-ГРОМАДСЬКЕ УПРАВЛІННЯ ОСВІТОЮ ЯК ОСНОВНИЙ НАПРЯМ ДЕМОКРАТИЗАЦІЇ
}

\author{
Інна Шоробура \\ Хмельницька гуманітарно-педагогічна академія \\ доктор педагогічних наук, професор, ректор
}

\begin{abstract}
Анотація. Громадське управління системою освіти - продуктивна діяльність суспільства, що містить в собі активний прояв громадянської позиції, суспільної ініціативи і соціальної відповідальності в управлінні системою освіти. Мета статті закцентувати питання державно-громадського управління освітою як основного напряму демократизації освіти. В освітянській сфері існує три рівні державного управління: національний рівень; регіональний рівень; районний рівень.

Ключові слова: освіта; управління; державно-громадське управління освітою.
\end{abstract}

General problem statement. The processes of democratization and publicity, the involvement of public control and the transfer of certain managerial functions from public authorities to other subjects of governmental activity in state regulation by public processes are inevitable if Ukraine strives to become a full member of the European space. Improving the governance of the education sector is gaining of special weight because through education not only a strong civil society can be formed, but new models of public administration in politics, the economy and the social sphere can be laid.

State-public administration acts as an innovation and provides for the development of harmonious social relations of the subjects of educational management on the basis of their consent and self-government, providing the necessary conditions for self-realization of each participant of the educational process, creation and functioning of collegial bodies of management.

Public administration of the education system is a productive activity of the society, which contains an active manifestation of civic position, social initiative and social responsibility in the management of the education system.

Analysis of recent research and publications. The problems of state and public administration are considered in the works of V. Andrushchenko, T. Butyrska, 
S. Goncharenko, V. Hrabovskyi, I. Ziaziun, V. Kremen, S. Krysiuk, V. Luhovyi, T. Lukina, A. Mazak, and others. Applied aspects were investigated by L. Karamushka B. Nilov, A. Ostapenko, N. Ostroverkhova, V. Pikelna, and others. The development of the scientific foundations of educational management are indicated in the works of scientists V. Afanasiev, E. Berezniak, D. Hvishiani, M. Darmanskyi, D. Deikun, P. Drobiazko, O. Zaichenko, S. Kalashnikova, L. Kalinina, Y. Konarzhevskyi, M. Kondakova, F. Panachyn, P. Rachenko, N. Samandas, J. Galanova, G. Fedorov, F. Shtykalo and others. Problems of improvement of the educational management system are revealed in the scientific works of V. Alfimov, E. Khrykov, V. Maslov, L. Danylenko, N. Ostroverkhova, Y. Konarzhevskyi.

The purpose of the article is to emphasize the issues of state-public administration of education as the main direction of democratization in the field of education.

The main material. Democratic approaches to administering in the educational sector of Ukraine have been implemented gradually - with the adoption of a number of legislative acts. Strategic goals, tasks, priority directions and main directions of transformations in the management of the educational system are defined by the Constitution of Ukraine, laws of Ukraine "On Education”, “On Preschool Education”, “On General Secondary Education”, "On Extracurricular Education", “On Vocational Education”, “On Higher Education”, Decrees of the President of Ukraine "On the National Program" "Children of Ukraine" and "On Immediate Measures to Ensure the Functioning and Development of Education in Ukraine", National Doctrine of Educational Development in the $21^{\text {st }}$ century. The documents reveal the transition from the traditional to the state-public system of administration by means of sharing the powers between central, regional and local authorities; intensification of participation of parents, stakeholders, board of trustees and other councils, philanthropists, public organizations, foundations, mass media in educational process of educational institutions, etc. For Ukraine, the process of decentralization in education management, expanding the autonomy of educational institutions, bringing them closer to the local environment, developing cooperation between educational institutions and public organizations remains relevant.

The influence of civil society institutions on state policy is in line with world standards, and increasing this influence is in line with the tendencies of information civilization development and modern scientific approaches [2]. Administration of education should be aimed at organizing optimal conditions for the functioning of education, creating 
the mechanism for its self-regulation at national, regional, local levels as well as in educational establishments and scientific institutions of education.

Analyzing the content of state-public administration of education, L. Haievska highlights the advantages and disadvantages of the state and public components. The researcher attributes the advantages of the state component: ideological and resource basis and practice of administrative management, which ensures maximum efficiency of educational sphere functioning. The researcher considers the following disadvantages of the state component: authoritarianism of managerial position; bureaucracy in decision-making and execution; use of state resources in the process of defining and implementing educational policy; observance of the power hierarchy; rejection of minority position. In general, the advantages of the public component include: independence of self-government bodies actions in joint management; a broad social basis for public participation in the co-management and activities of educational institutions; practice of open and public discussions and decision making; promoting the initiative; minority views. The disadvantages of the community component are: potential lack of resources and opportunities for financing development projects; insufficient level of participants competence [1].

The essence of state-public administration in modern education implies coordinated interaction between the state and the community in solving various educational issues related to the ability to responsibly and effectively influence educational policy, decision-making, creating a favourable social environment for students, etc. [5].

At the same time, state-public administration of education is defined as the integration of three work directions: democratization of the activity of public authorities and management of education; development of self-governing associations of participants in educational activities (professional associations of teachers, student and parent self-government bodies of all levels); organization of public education management bodies, where all sections of the population are represented [4].

There are three levels of state administration in the educational sphere: the national level (Ministry of Education and Science of Ukraine (MES), ministries and departments of Ukraine, Higher Attestation Commission (HAC)); regional level (education department of regions of Ukraine); district level (local government bodies, district education departments, education departments of the united territorial communities).

$\mathrm{H}$. Yelnikova proves that involvement of public in making management decisions at different levels of the management vertical can be done in different ways, and suggests models of state-public administration. 
The first model of structural and public support implies that the subordination vertical of general secondary education management is accompanied at each stage by a corresponding social structure. The main task of the public structures is an independent examination of the state of affairs in education and dialogue with the authorities to establish a balance of interests of the public and the governing bodies of general secondary education. Public structures function alongside the state government structures. They establish communication links within and between each management levels. In the author's opinion, the result is to achieve a balance between the requirements of the state and the demands of citizens [3].

The second model is the model of information-public support, which combines the efforts of state education management structures with public structures of institutions of general secondary education in order to regulate the oncoming information flows. Determination stream of information (regulatory and social-value) moves from the top to the bottom. From the bottom up there is a flow of a pretentious information (reaction of doers and public to the determination information). At each stage of management, an adaptation structural unit is created, the main purpose of which is an adjustment of oncoming flows of information and determination of the vector of preferences. Processed information is transmitted to the decision-making structure. The information adjustment process adapts the management decision to the external and internal conditions by establishing a balance of interests of all participants of educational process.

The third model of the subordination-intermediate partnership provides the increase of the mobility of subordination relations all over the vertical. This is because the public is involved in the fulfilment of tasks and the relationships are temporarily transformed into partnerships, expanding horizontal connections. After achieving each interim goal, the temporary team is dismissed and the subordination vertical is restored. The main purpose of this model is to create a mechanism of subordination and partnership relations for the mutual adaptation of multidirectional activities according to the general vector of preferences [3].

The main tasks of state institutions, which administer education at all levels (Ministry of Education and Science of Ukraine, Committee of Verkhovna Rada of Ukraine on Science and Education, city, district departments of education at state administrations of cities, etc.), are: implementation of state policy standards in the field of education; strengthening the material base of educational institutions; providing conditions for implementation of citizens' right guaranteed by the Constitution of Ukraine to obtain education in accordance with their personal needs, individual abilities and opportunities; partial management in educational institutions; organization of educational-methodical and staff support in educational 
institutions; control over compliance with legal acts on education and science of the state standard; certification of educational institutions.

The main task of state-public administration is to ensure the dialogue between state administration structures and public municipality, to establish a balance between state control and self-organization that take place in socio-pedagogical systems [6]. In addition, the tasks of such administration are implementation of teachers', students' and their parents' rights, defined by law, to participate in the educational institution management; democratization of state administration of education; meeting the needs and interests of participants in the educational process; development of coherent mechanisms for resolving conflicts between all agents.

The functioning of state-public system of education administration is not possible without active voluntary participation of the general public.

Peculiarities of state-public administration of education are the following: presence of state structure of administration of education; presence of public structure of administration of education; coordinated and generally accepted distribution of powers and responsibilities between state and public subjects of administration of education at all levels; approved by organs of state and public administration of education system of settlement of disputes and controversial issues that arise between them.

In Ukraine the community councils and boards operate under the central bodies, and representatives of the public are board members; at the regional level the community councils have been founded and local educational districts with electoral educational boards have been re-established. The districts' powers are the following: solution of the problems related to education, upbringing, crime prevention, social protection, local community development. Also, there are boards of trustees, councils of educational establishments comprising parents, students, active citizens who remain deeply rooted in national education. At the local and regional levels there are councils of student self-governance, parents' associations, councils of rectors of higher educational establishments. There is also the Union of rectors of higher educational establishments, the Association of school heads of Ukraine, the Association of directors of out-of-school educational establishments, and other organizations. Public educational structures are often formal. They do not influence upon the educational sphere processes as they do not possess all the necessary and sufficient powers.

According to L. Haievska, the principles of state-public administration of education play an important role in understanding the essence of this phenomenon. They include: independence and equity of organs of state-public administration of education; complex 
application of economic and other resources of state and society by subjects of state-public administration of education; targeted orientation of activities of subjects of state-public administration of education towards fulfillment of needs and interests of all those involved in the educational process, society, and state; legal substantiation of claims of educational activities agents for participation in state-public administration of general secondary education at the level of establishment of general education, at the local, regional and central levels; openness and transparency in accordance with which activities of subjects of statepublic administration of education are open for all participants of educational process and are maintained by receiving information; freedom and independent activities that mean the possibility for every subject of state-public administration of education to choose methods and tools to carry out administration functions freely and at the same time remain active and independent; coordinated distribution of powers and spheres of responsibility between state and public organs of administration of education at all levels and at the stage of functioning and development; provide powers to organs of administration of education in the state vertical power structure from the top down, and in the public power structure - vice-versa, from bottom to top; civilized settlements of conflicts and controversial issues between state and public organs of administration at all levels by means of implementation of generally accepted mechanisms and procedures [1]. Today it is very important to activate public component within state-public administration of education in Ukraine as it is a condition for European integration.

The prospects for further studies in this direction. State-public administration of education involves structures of civil society - voluntary associations, unions and organizations of citizens to implement public educational policy on democratic principles.

Introduction and functioning of the model of state-public administration of education has an integral part. Community and education can continue developing only through joint efforts. The benefits for educations concern formation of active citizenship, possibilities for its realization, increasing of the level of professionalism, raising additional funds for educational establishment activities, and development of educational establishment in general. The benefits for the community include development of active citizenship among the community members. 


\section{References:}

1. Haievska L. O. Rozvytok derzhavno-hromadskoho upravlinnia zahalnoiu serednoiu osvitoiu v Ukraini (druha polovyna XIX pochatok XX st.): avtoref. dys. d-ra nauk z derzh. upr. Kyiv, 2010. 36 s.

2. Hrabovskyi V.A. Derzhavno-hromadske upravlinnia zahalnoiu serednoiu osvitoiu na raionnomu rivni: dys... kand. nauk z derzh. upr.: 25.00.02. Kyiv, 2006. $233 \mathrm{~s}$.

3. Yelnikova T.V. Teoretychni pidkhody do modeliuvannia derzhavno-hromadskoho upravlinnia Dyr 2003 \#40 (280), S. 10-11

4. Kaminska Ye. I. Derzhavno-hromadske upravlinnia v zahalnoosvitnomu navchalnomu zakladi. Kh.: Vyd. hr. «Osnova», 2013. $112 \mathrm{~s}$.

5. Komarnytskyi M. S. Derzhavno-hromadska systema upravlinnia osvitoiu. Aspekty samovriaduvannia. 2000. \#3. S. 34-35.

6. Lebid Ye. Derzhavno-hromadskyi typ upravlinnia osvitoiu: yevropeiskyi dosvid ta ukrainski realii [Elektronnyi resurs] Rezhym dostupu: http://www.europexxi.kiev.ua

\section{Список використаних джерел:}

1. Гаєвська Л. О. Розвиток державно-громадського управління загальною середньою освітою в Україні (друга половина XIX початок XX ст.): автореф. дис. д-ра наук $з$ держ. упр. Київ, 2010. 36 с.

2. Грабовський В.А. Державно-громадське управління загальною середньою освітою на районному рівні: дис... канд. наук з держ. упр.: 25.00.02. Київ, 2006. 233 с.

3. Сльнікова Т.В. Теоретичні підходи до моделювання державногромадського управління Дир 2003 №40 (280), С. 10-11

4. Камінська Є. I. Державно-громадське управління в загальноосвітньому навчальному закладі. Х.: Вид. гр. «Основа», 2013. 112 с.

5. Комарницький М. С. Державно-громадська система управління освітою. Аспекти самоврядування. 2000. № 3. С. 34-35.

6. Лебідь Є. Державно-громадський тип управління освітою: європейський досвід та українські реалії [Електронний ресурс] Режим доступу: http://www.europexxi.kiev.ua 